\title{
Research on the Content of Legal Education in University of Science and Engineering Based on Risk Prevention
}

\author{
Hongzhen Lin \\ School of Hengda Management \\ Wuhan University of Science and Technology \\ Wuhan, China 430081
}

\begin{abstract}
The purpose of this paper is to research the content of legal education in University of science and engineering. Using the method of document study and investigation obtained necessary data in order to deeply, correctly understand the content of legal education problem. The legal education has become more and more important problem. The absolute risk aversion is often difficult, but it can be integrated in strengthening risk prevention education, such as risk correction diversified investment and risk diversification through insurance transfer, improving risk prevention awareness and Entrepreneurship of College Students the ability of venture control. Effective measures and suggestion to improve legal education in University of science and engineering should be put forward based on risk prevention. The conclusion is that it is important for University of science and engineering to optimize the content of law teaching, improve risk prevention ability.
\end{abstract}

Keywords-college students; entrepreneurship law; risk prevention; education

\section{INTRODUCTION}

The speed of our country's economic development has entered an unprecedented stage of development, and many social contradictions have emerged. The legal literacy and legal education of college students must also adapt to the social and economic development, and need to make appropriate adjustments and changes. College students especially the non-legal professional knowledge of law students lack of legal concepts, legal literacy is relatively short thin, generally not high. The legal education of nonlegal majors in Institutions of higher learning has not yet formed a normal mechanism and relatively perfect legal education system, which is often subordinate to ideological education [1]. The law students is the main force in the construction of socialist cause in China, they will be engaged in the work of social construction in all areas of society an important task, is an important source of future members of the mainstream of society, but also produce the leading figures in the field of. Establish the legal consciousness is the

This research was financially supported by National social science fund education general project "entrepreneurial law education research based on risk control in science and Engineering University ", No. BIA170192 ideological basis of good behavior of college students in non-legal professional and important ideological content, not the ideological basis and ideological content, the real implementation of building a socialist country ruled by law and the rule of law is likely to encounter obstacles. If students of non-legal majors have higher legal consciousness, they will be able to control their behavior in their work and life.

Legal education is a broad category of education, which includes professional legal education and non-professional legal education. Legal education refers to the cultivation of legal talents of each grade school system of law education in China also belongs to the category, including the legal theory and legal research on teaching, education requirements itself relatively high quality. [2]The legal education of non-law majors including comprehensive law, including the legal education and legal professional schools in Colleges and universities, non-legal education legal profession is more highlights the significance of legal education of College Students' legal literacy.

\section{THE FUNCTION OF LEGAL EDUCATION IN UNIVERSITIES OF SCIENCE AND ENGINEERING}

\section{A. Constructing Legal Knowledge System}

Legal knowledge is mainly composed of two parts: one is to establish a rule of law knowledge, the so-called laws and regulations system; the two is about the principle of legal knowledge in knowledge, the so-called legal principle or legal theory. The study of law and the law of common sense, is not only familiar with some basic requirements of laws and regulations, and master certain generally applicable law principle. [3] Generally speaking, the basic legal knowledge can be summarized into three aspects: first, on the basic concept and spirit of modern knowledge, is mainly the concept of law, value, function and role of knowledge. Second, the main content and characteristics of the current law in a country, mainly refer to the basic structure of the legal system of a country and the basic content of the major legal departments of the country. Third, knowledge of procedural law seeks legal rights and resolving disputes 
through legal means. The main ways transmit legal knowledge to the educated.

The legal education in Colleges and universities should first of all bring legal knowledge and legal system into the knowledge structure of non-law Majors in universities. Legal knowledge is the material carrier of non-legal majors in Colleges and universities to improve their legal literacy, but how to grasp and transfer good legal knowledge is related to their acceptance of legal education, ways and means. The legal profession student legal knowledge awareness and cognitive ability determine college students as the legal literacy of ordinary citizens. It also affects the legal consciousness of the whole nation, but also the legal system of the implementation guiding effect.

\section{B. The Response of Innovation and Entrepreneurship to the Legal Education in Colleges and Universities}

The content, structure and system of legal knowledge are influenced by the development of the times to a great extent. With the change of times and legal education, it is necessary to change the focus of legal knowledge in accordance with the characteristics of the times. Therefore, we must conform to the times of the legal structure system. [4]This is not only the need of social development, but also the history of the development of new China's law requires that legal knowledge be sent to the quality of the people. At the same time, the legal education in China is not just the new situation on the basis of China of their legal system construction, quickly establishing a number of special law schools, and universities also setting up many the Department of law, and the legal situation of coexistence of higher education. Needing to establish and perfect the legal system, legal construction is able to continue restoring and strengthening legal education [5].

\section{The Need to Guard against Entrepreneurial Risks}

College Students' entrepreneurial risk refers to the risk of college students in the process of entrepreneurship. It is due to inadequate entrepreneurial uncertainty, entrepreneurial opportunities and entrepreneurial complexity. The limited capacity and strength of the resulting new entrepreneurial activities deviate from the expected goal of the possibility and consequences. Student entrepreneurs' enterprises are often small in scale and financial strength is weak. The work is in the initial stage. Risk of venture period will make the enterprise difficult and may even make the new enterprise suffer the crowning calamity. There is nothing definite except risk. The risks of entrepreneurship are inevitable. There is no zero risk entrepreneurship.

\section{REASON ANALYSIS OF ENTREPRENEURIAL RISK}

\section{A. Awareness of Entrepreneurial Risk}

Some college students are not aware of the reality and potential risks that entrepreneurship faces when they are in the preparatory stage of entrepreneurship, and they are not prepared for setbacks, Psychological preparation, resulting in them in the face of entrepreneurial risk, found that the ideal and reality gap is great, mental pressure surge, helpless. Due to the lack of social experience, understand the work practice, many college students do not have business knowledge and skills, such as do not understand the relevant policies and regulations of entrepreneurship, and lack the ability of enterprise management and market operation, does not have the means to strengthen coordination of team members and team cohesion.

\section{B. Lacking of Entrepreneurial Experience}

As a result of long-term acceptance of examination oriented education, college students generally lack innovative spirit and practical ability in finance, marketing and human resources and other aspects of management, only on paper, not only a single knowledge, lack of practical verification, but also the use of knowledge, the ability to adapt to circumstances inadequate. Because of the market do not understand, do not understand the industry, most of the students will have empty talk in entrepreneurial project selection, and not

Market environment, industry demand research, depth review, consider various entrepreneurial conditions, carefully select entrepreneurial projects, and comprehensive planning business plan. Most of the students will encounter difficult to raise funds, capital chain disruptions in the early days of all problems, this is not only because the students will not use the relevant financing policy, financing channels for a single; there is also a part of the reason is the operation procedures and management of college students are not familiar with the fund, the fund operation skilled, fund management is not scientific.

\section{Lacking of Capacity to Obtain Entrepreneurial Resources}

Entrepreneurship is a huge, complex and difficult project, entrepreneurship is not cited "source water", "like trees planted". Each individual entrepreneurs, must have its inevitable conditions, is its own resources. The process of entrepreneurship is the process by which entrepreneurs build, integrate, and expand resources. Social resources include family resources, such as family financial support, business experience, learning opportunities and connections, and even customer resources, including their own professional resources and network resources.

Due to the long living on campus, students directly grasp the social resources are very limited, and enterprise creation, market development, product promotion and other work needs to mobilize social resources, students will feel very difficult in this respect. Students in the entrepreneurial process itself is easily confused, if compared with people with entrepreneurial experience and social resources, longterm in the campus environment of college student entrepreneurs will be at a disadvantage in social experience, interpersonal relations, so inevitably degenerate emotions in the face of the entrepreneurial process of changing, can't adapt to the business environment. 


\section{COUNTERMEASURE OF LAW AND RISK PREVENTION EDUCATION FOR COLLEGE STUDENTS}

\section{A. Strengthening Market Risk Education and Improving Market Competitiveness}

Before starting a business, college students must find the right starting point for entrepreneurship and do a down-toearth and scientific market research, not just an idealistic deduction. College students should avoid impetuous psychology, choosing the right time, suitable project and suitable scale to start an undertaking. For the hands of no more funds, and no business experience of entrepreneurs, college students may wish to start from small business. Although the development of small business is slow, but they can feel alarmed, and laid the foundation for the next big career. This is a lot of student entrepreneurs' wise remark of an experienced person.

The policy risk, such as the national and local laws and regulations, industrial policy, but the biggest risk is temporary, sudden introduction of policies and regulations. The decision risk, different decision schemes have different opportunity costs and different risk. Market risk is the core risk factor, such as the emergence of more powerful competitors, resulting in increased competition, changes in the market situation. Market risks should be strengthened education. As mentioned earlier, entrepreneurship is accompanied by risk, and risk is essentially an uncertainty, that is, the final outcome of events has a variety of possible states. [6] Perhaps the number and extent of these states can be roughly estimated based on empirical knowledge and historical data, but it is impossible to predict exactly what the outcome will be. That is to say, in the face of uncertain market, entrepreneurs can't accurately predict risks. Therefore, entrepreneurs' strategic behavior is only a means based orientation, namely from the existing means of using these means to create explicit results for profit or loss. [7] The possible loss in the process of entrepreneurship, entrepreneurs generally have psychological preparation, but they are significantly different characteristics. The risk must be controlled in the affordable range run beyond the affordability of their bottom line. Of course, the size of an entrepreneur's loss is different from person to person, and its threshold depends on the resources the entrepreneur has on hand.

Small-scale constant correct expansion risk, such as enterprise scale expansion, business expansion, project expansion and so on, if the expansion is blind, and not the ability of enterprise, market demand, is extremely dangerous. Entrepreneurs did not grasp the risks and risk control ability of entrepreneurial projects, entrepreneurs can give up, turn in some risk profit enterprises have more moderate, grasp the risk control and have the ability to bear the risk ability project. [8] It is embodied in three aspects: the ability of the staff, the loss of personnel and the moral hazard of the personnel.

\section{B. Paying Attention to the Education of Management and Building Team}

The entrepreneurial team refers to in the beginning, by a group of special groups; each one has his good points shared responsibility, willing to common business goal member. Turning a personal idea into reality requires a range of skills rather than relying solely on individual capabilities, and a good entrepreneurial team can make start-ups develop rapidly. But at the same time, risk also contains, the greater the strength of the team, the greater the risk. In the process of entrepreneurship education in Colleges and universities, education should be team work through them, to cultivate students' innovation, organizational planning, communication, coordination and other aspects of the compromise listening ability. Enterprises want to achieve sustained and stable development, we must grasp all kinds of tubes Management including human resource management, financial management and production management. Scientific and good management can coordinate all kinds of relationships inside and outside the enterprise. Ensuring the harmonious operation of enterprises can bring into full play the best function as the economic subject. Therefore, college students in the process of entrepreneurship can be established through formal and rigorous management system, improving the enterprise's standardization and employee's consciousness. Strengthening the management of advanced knowledge and management experience can improve the competitiveness of enterprises and establish an internal staff training system.

\section{Innovating Education Model and Strengthening Entrepreneurship Practice}

It should pay attention to diversified education meets the needs of students at different levels. The core objective of entrepreneurship education is not the creation of entrepreneurs, the big boss, but through education students meet the needs of multi-level and occupation ability, to help students improve their self understanding, self mining potential. In the course of future development innovation is entrepreneurial personality. The creative education in schools can adopt experiential learning combining rationality and sensibility, such as career personality interviews, talent demand market research, target occupation, post research, professional experience, and recruitment and so on. Through a series of social practice activities, let the students go deep into social life; stimulate the students' love and enthusiasm for learning. At the same time, providing students with the necessary opportunities for vocational skills training improve the students' own personality, character creation and innovative character, and lay a good foundation for students' career.

The school can set up a student innovation fund through the mode of project funding and mentor pairing. Students actively carry out innovative activities of various types of College students. Through the tutor's guidance to the students' innovation and entrepreneurship project team, they help the students to enter the laboratory and the factory, exercising practical skills, enhancing their awareness of entrepreneurship, and cultivating the spirit of cooperation. 
Schools can use their own advantages, integration of social resources, entrepreneurship, training and textual research as the carrier, and actively carry out various types of training and research activities [9]. Through these training, students feel the operation, management, division of labor, strategic planning, production and grasp the real enterprises various decision situations encountered in the operation of industry, to analyze and assess the problems and results of operations, to enable students to experience and feel more deeply on the enterprise management in all kinds of knowledge and skills. Diversify portfolios diversify risk education. Risk diversification refers to the fact that entrepreneurs can reduce the overall risk through the scientific investment portfolio, such as choosing the right portfolio of investment and the combination of investors, so as to achieve effective risk control. The main idea from portfolio theory, the basic idea is that if an enterprise has a variety of different types of environment facing the business combination, can make the risk of moderate dispersion, because some small business risk, the risk of some big business, on average, can get a relatively modest level of risk. The main body of the venture is diversified and diversified in different business activities. [10]

\section{CONCLUSION}

The State advocates promoting entrepreneurship and promoting employment. But entrepreneurship is fraught with risk. University graduates entrepreneurs just step the society and lack of the entrepreneurial knowledge and ability. They do not understand and policy and market and don't know how to seek available resources. Personal pressures are also risk factors for their entrepreneurial process inevitably. These risk factors for their success rate hit many discount. In general, entrepreneurial risk can't be absolutely avoided, but the entrepreneurial risk can be controlled by strengthening risk education. College student entrepreneurs need choices and trade-offs between risk and return, neither to return regardless of the size of the risk, not because of fear of risk and missing opportunity. To achieve the goal in the premise, through the integrated use of the risk control strategy, reduce the risk of business on the road, the scope of the enterprise can bear, to ensure the healthy development of enterprises. Universities of science and technology increase the learning of law course for students of through various publicity channels, not only give students ways of learning legal knowledge, but provide the public platform to learn the morality of law for non-law majors and arouse students' thinking. It is helpful for non-law majors to pay attention to the course of law and raise the consciousness of law and cultivate certain legal belief. Therefore, to explore the essence of college students venture and cause, how to study under the conditions of the existing various preventive measures to effectively control the business risk, it has certain practical significance to promote the sustainable development of healthy and stable business students.

\section{REFERENCES}

[1] Huang Zhaoxin, Huang Lijun, Song Zhaohui. Legal Education For College Students: Necessity, Problems And Suggestions [J]. Chinese Higher Education Research, 2012 (11): 76-78.

[2] Wang Debin. On Legal Education For College Students And The Construction Of Its Curriculum System [J]. Heilongjiang Higher Education Research, 2011 (1): 167-169.

[3] Zhu Wensheng. Research On The Legal Risk Prevention And Control System Of University Students' Entrepreneurship. From The Perspective Of The Perfection Of Entrepreneurship Legal Education In Colleges And Universities [J]. Ideological And Theoretical Education, 2013 (5): 66-70.

[4] Zhang Shuqin. A Brief Comment On The Improvement Of Legal Education For College Students. [J]. legal system and society, 2012 (6): 234-235.

[5] Wang Hui. Construction Of Entrepreneurship Legal Education Curriculum System [J].. Education and profession, 2013 (11): 140141.

[6] Tang Yanchun, Ma Fuyun, Li Ping. Problems And Strategies For The Development Of Legal Education For College Students [J]. Journal of Yunnan Institute of socialism, 2014 (01): 138-141.

[7] Zhang Qingzhu, Zhu Hong, Li Zhiyi. Research On The Background, Impetus And Guarantee Mechanism Of Innovation And Entrepreneurship Education $[\mathrm{J}]$. higher engineering education research, 2017 (3): 162-165.

[8] Xue Hao, Chen Wanming, Zhang Bing, et al. Misunderstandings And Countermeasures In Entrepreneurship Education In Colleges And Universities [J]. higher education research, 2016 (2): 74-78.

[9] Chen Chen. Students Of Small Micro Entrepreneurs Risk Dominant Education And Prevention Of $[\mathrm{J}]$. Decision And Information Management, 2015 (4): 67-68

[10] Dong Ying, Zheng Yiqu, Li Jun. Discussion On The Mode Of Entrepreneurship Education In Local Universities [J]. higher engineering education research, 2016 (4): 95-98. 